Supplement of The Cryosphere, 12, 2667-2688, 2018

https://doi.org/10.5194/tc-12-2667-2018-supplement

(C) Author(s) 2018. This work is distributed under

the Creative Commons Attribution 4.0 License.

(c) (1)

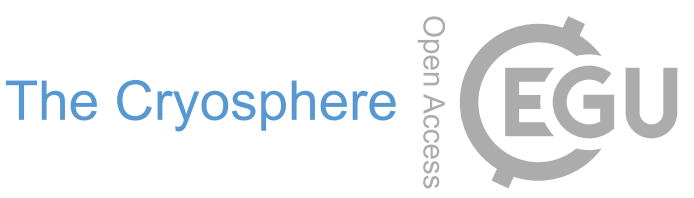

Supplement of

\title{
Characteristics and fate of isolated permafrost patches in coastal Labrador,
} Canada

\section{Robert G. Way et al.}

Correspondence to: Robert G. Way (robert.way@queensu.ca)

The copyright of individual parts of the supplement might differ from the CC BY 4.0 License. 


\section{Section S1: Uncertainties in permafrost thickness estimation and presentation with ERT}

ERT profiles are presented as model blocks because they are effective at showing contrast with depth. Profiles were faded in areas with lower calculated sensitivity values $(<0.1$; RES2DINV method) to limit the area considered during analysis. Model block sensitivity values are a measure of the amount of information about the resistivity contained in the measured block and are discussed in detail in the RES2DINV software manual that was produced based on Loke and Barker (1996) and Loke et al (2003). Higher sensitivity values correspond to more reliable model resistivity values. The selection of values less than 0.1 was on the basis of manual interpretation of the profiles.

In order to estimate permafrost thicknesses from ERT alone we combined frost table probing and modelled resistivities for each of the ERT profiles. First, we matched the xyz block resistivities at a depth of 0.5-1.0 $\mathrm{m}$ to the frost table measurements taken along the ERT profiles. Where a frost table was recorded, the apparent resistivity in the layer from 0.5-1.0 m was linked to frozen ground presence (value of 1 in the subsequent logistic regression). Where no frost table was recorded within the top $120 \mathrm{~cm}$ (maximum probing depth), the apparent resistivity for 0.5 $1.0 \mathrm{~m}$ was associated with unfrozen soil (value of 0 in the logistic regression). Data from all sites were pooled for the logistic regression analysis (Fig. S1). The best-fit curve was then used with the ERT modelled apparent resistivity blocks to generate permafrost probabilities (Fig. S2). This approach assumes that the substrate in the upper layers is representative of those at depth which may not always be correct. Permafrost probability typically dropped very sharply with depth, from $>90 \%$ to $<10 \%$ between two vertically adjacent model blocks. At some locations, a single block with intermediate probability existed between these two extremes. Based on these results, 
in the absence of ground temperatures measured in boreholes, we adopted a permafrost thickness error of $\pm 0.5 \mathrm{~m}$, which is equivalent to \pm one model block for most profiles.

\section{Section S2: Compiling daily climate input data for the NEST model}

The NEST model requires continuous daily climate inputs of minimum and maximum air temperatures, precipitation, vapour pressure, solar radiation and wind speed. We compiled the input data based on climate station observations and gridded datasets for the period 1901-2016. Daily air temperature and precipitation observations were available during 1938-2016 for Cartwright station, and 1976-2016 for Blanc Sablon station from Environment and Climate Change Canada. McKenney and colleagues (McKenney et al., 2006; Hutchinson et al., 2009; McKenney et al., 2011) in Canadian Forest Service developed $10 \mathrm{~km}$ by $10 \mathrm{~km}$ resolution gridded datasets for air temperature (minimum and maximum) and precipitation (from 1950 to 2013 for daily and 1901 to 2013 for monthly). The year 1900 was infilled by linearly extrapolating the monthly data for model initialization purpose. We downscaled the monthly data to daily from 1900 to 1949 using daily gridded data from 1950 to 2013 as templates (see appendix in Zhang et al., 2012). Based on this gridded data, we extended the daily climate station data to 1900 .

From 2017 to 2100, we used three climate projections under RCP 2.6, 4.5 and 8.5 scenarios based on an ensemble of 29 climate models developed by the Coupled Model Intercomparison Project Phase 5 (CMIP5) (Taylor et al., 2012). The data are in common 1 degree by 1 degree global grid provided by Environment and Climate Change Canada (http://climatescenarios.canada.ca/index.php?page=gridded-data). The climate record of the coastal Labrador region is considered to be highly variable and its future evolution is uncertain due to broad-scale uncertainties associated with ocean-atmospheric teleconnections and other factors (Brown et al., 2012; Way and Viau, 2015; Grenier et al., 2015). The authors have made the choice to use a simple downscaling method (delta) instead of higher complexity approaches because in coastal Labrador there is considerable potential for introducing additional sources of error through ocean-atmospheric-cryosphere feedbacks and other interactions that are not consistently represented by GCMs (Grenier et al., 2015; Ekström et al., 2015). We do acknowledge that the 
evolution of Tmin and Tmax and year-to-year variability may impact the potential evolution of permafrost. However, there is not a consistent set of evidence that more complicated downscaling methods are inherently more accurate relative to delta approaches for simple variables like air temperature (Ekström et al., 2015). We first calculated anomalies (difference for air temperature and relative difference for precipitation) with respect to the reference period of 1976-2005, then we derived the future monthly values based on the anomalies and the averages during the reference period at each site. We used the anomalies of air temperature for both the monthly averages of daily maximum and minimum air temperatures. The monthly projections were downscaled to daily using daily gridded data from 1950 to 2013 as templates. Environment Canada and National Research Council of Canada (2007) compiled hourly climate datasets and computed solar radiation for some climate stations in Canada, including Cartwright station. We directly used these data to calculate daily vapour pressure, solar radiation and wind speed for Cartwright when data are available (1964-2005). For other periods when data were not available at Cartwright and at Blanc Sablon, we estimated daily vapour pressure and solar radiation based on the following equations (see appendix in Zhang et al., 2012)

$V=\alpha V_{s, T m}$,

$R=R_{0} a_{1}\left[1-\exp \left(-a_{2} \Delta T^{a 3}\right)\right]$,

where $V$ is estimated average water vapour pressure for a day (mbar) and $V_{s, T m}$ is saturated water vapour pressure (mbar) at the daily minimum air temperature $T_{m}\left({ }^{\circ} \mathrm{C}\right) . R$ is the estimated daily total solar radiation $\left(\mathrm{MJ} / \mathrm{m}^{2} / \mathrm{d}\right), R_{0}$ is daily total solar radiation above the atmosphere $\left(\mathrm{MJ} / \mathrm{m}^{2} / \mathrm{d}\right)$, and $\Delta T$ is the diurnal temperature range $\left({ }^{\circ} \mathrm{C}\right) . \alpha, a_{1}, a_{2}$, and $a_{3}$ are empirical parameters (no units) determined based on the hourly data during 1964-2015 at Cartwright station (1.05, 0.79, 0.02, 2.0, respectively). Wind speed during 1954-2005 are from observations at Cartwright climate station. In other periods, we directly used the observed wind speed during 1954-2005 to fill the data gaps. 
Table S1: Parameters for ground temperature modelling with NEST at Cartwright and Blanc Sablon.

\begin{tabular}{|c|c|c|c|}
\hline Parameter & $\begin{array}{l}\text { Cartwright } \\
\text { (WJD02) }\end{array}$ & $\begin{array}{l}\text { Blanc Sablon } \\
\text { (WJD03) }\end{array}$ & $\begin{array}{l}\text { Data sources or estimation } \\
\text { methods }\end{array}$ \\
\hline Latitude $\left({ }^{\circ} \mathrm{N}\right)$ & $53.7^{\circ} \mathrm{N}$ & $51.45^{\circ} \mathrm{N}$ & Based on field data. \\
\hline Peat thickness & $1.20 \mathrm{~m}$ & $1.75 \mathrm{~m}$ & Based on field data. \\
\hline Texture of organic layers & Undecomposed peat & Undecomposed peat & Based on field data. \\
\hline $\begin{array}{l}\text { Organic matter content in } \\
\text { mineral soils }\end{array}$ & $\begin{array}{l}1.2-1.5 \mathrm{~m} \text { : decreases from } 100 \% \text { to } \\
5 \%, 1.5-3.2 \mathrm{~m}: 5 \% \text {, then linearly } \\
\text { decreases to } 1 \% \text { at } 10 \mathrm{~m}\end{array}$ & $\begin{array}{l}1.75-2.0 \mathrm{~m} \text { : decreases from } 100 \% \\
\text { to } 5 \%, 2.0-3.2 \mathrm{~m}: 5 \% \text {, then linearly } \\
\text { decreases to } 1 \% \text { at } 10 \mathrm{~m}\end{array}$ & $\begin{array}{l}\text { Estimated based on the visual } \\
\text { expression of the core. }\end{array}$ \\
\hline $\begin{array}{l}\text { Texture of the organic matter in } \\
\text { mineral soils }\end{array}$ & $\begin{array}{l}\text { From hemic to well decomposed at } \\
\text { depth }\end{array}$ & $\begin{array}{l}\text { From hemic to well decomposed at } \\
\text { depth }\end{array}$ & $\begin{array}{l}\text { Estimated based on the visual } \\
\text { expression of the core. }\end{array}$ \\
\hline Sub-peat stratigraphy & $1.2-3.2 \mathrm{~m}$ : silt, $3.2-10 \mathrm{~m}:$ sand & $1.75-3.2 \mathrm{~m}:$ silt, $3.2-10 \mathrm{~m}:$ sand & Estimated based on the cores. \\
\hline Depth to bedrock & $10 \mathrm{~m}$ & $10 \mathrm{~m}$ & Based on field data. \\
\hline $\begin{array}{l}\text { Volumetric fraction of quartz in } \\
\text { mineral soil }\end{array}$ & 0.1 & 0.1 & Assumed based on Dell (1959). \\
\hline Thermal conductivity of rock & $1.5 \mathrm{~W} /(\mathrm{m} \cdot \mathrm{K})$ & $1.5 \mathrm{~W} /(\mathrm{m} \cdot \mathrm{K})$ & Based on Pollack et al. (1993) ${ }^{1}$. \\
\hline Geothermal heat flux & $1.02 \mathrm{~W} / \mathrm{m}^{2}$ & $0.54 \mathrm{~W} / \mathrm{m}^{2}$ & $\begin{array}{l}\text { Calibrated based on observed } \\
\text { ground temperature. }\end{array}$ \\
\hline Lateral surface water outflow ${ }^{2}$ & $\begin{array}{l}\text { Water table reduces } 10 \% \text { daily } \\
\text { when it is above ground surface }\end{array}$ & $\begin{array}{l}\text { Water table reduces } 10 \% \text { daily } \\
\text { when it is above ground surface }\end{array}$ & $\begin{array}{l}\text { Assumed based on local } \\
\text { topography. }\end{array}$ \\
\hline Lateral surface water inflow & 0 & 0 & Assumed. \\
\hline $\begin{array}{l}\text { Lateral ground water inflow and } \\
\text { outflow }\end{array}$ & 0 & 0 & Assumed. \\
\hline Vegetation type & Shrubs & Shrubs & Based on field data. \\
\hline $\begin{array}{l}\text { Leaf area index (peak growing } \\
\text { season) }\end{array}$ & 0.5 & 0.2 & $\begin{array}{l}\text { Based on visual expression of } \\
\text { field conditions. }\end{array}$ \\
\hline Snow wind-scouring factor ${ }^{3}$ & 0.83 & 0.85 & $\begin{array}{l}\text { Calibrated based on near surface } \\
\text { soil temperature. }\end{array}$ \\
\hline Surface albedo (no snow) & 0.1 & 0.1 & $\begin{array}{l}\text { Based on Houldcroft et al. } \\
\text { (2009) }\end{array}$ \\
\hline
\end{tabular}

\footnotetext{
${ }^{1}$ The medium value of the observations in Canada and some surrounding sites in U.S. with observation depth $<120 \mathrm{~m}$ (756 sites).

${ }^{2}$ See Zhang et al. $(2002,2012)$ for detailed description.

${ }^{3}$ Snow wind-scouring factor is the fraction of snowfall blown away from the site.
} 
Table S2. Characteristics of peatland permafrost mounds surveyed using ERT.

\begin{tabular}{|c|c|c|c|c|c|c|}
\hline $\begin{array}{c}\text { ERT } \\
\text { Profile }\end{array}$ & $\begin{array}{l}\text { Mound } \\
\text { ID }\end{array}$ & $\begin{array}{l}\text { Frost table } \\
\text { depth }(\mathrm{cm})\end{array}$ & $\begin{array}{l}\text { Maximum mound } \\
\text { height (m) }\end{array}$ & $\begin{array}{c}\text { Inferred permafrost } \\
\text { depth }(\mathrm{m})\end{array}$ & $\begin{array}{l}\text { Calculated } \\
\text { permafrost } \\
\text { thickness (m) }\end{array}$ & $\begin{array}{l}\text { Excess ice } \\
\text { fraction }^{a}\end{array}$ \\
\hline 1 & $\mathrm{P} 1$ & 60 & 0.9 & $3.4 \pm 0.5$ & $2.3-3.3$ & $0.28-0.40$ \\
\hline 1 & $\mathrm{P} 2$ & 57 & 1.2 & $4.5 \pm 0.5$ & $3.4-4.4$ & $0.28-0.36$ \\
\hline $1 \& 2$ & P3 & 60 & 1.4 & $6.5 \pm 0.5$ & $5.4-6.4$ & $0.22-0.26$ \\
\hline 1 & $\mathrm{P} 4$ & 62 & 0.4 & $4.3 \pm 0.5$ & $3.2-4.2$ & $0.11-0.14$ \\
\hline 3 & P5 & 58 & 0.4 & $2.5 \pm 0.5$ & $1.4-2.4$ & $0.17-0.30$ \\
\hline 3 & P7 & 54 & 1.1 & $4.5 \pm 0.5$ & $3.5-4.5$ & $0.24-0.32$ \\
\hline 3 & P8 & 41 & 0.5 & $1.2 \pm 0.5$ & $0.3-1.3$ & $0.36-1.59$ \\
\hline 4 & P9 & 61 & 0.5 & $3.4 \pm 0.5$ & $2.3-3.3$ & $0.14-0.20$ \\
\hline 4 & P10 & 65 & 0.8 & $2.3 \pm 0.5$ & $1.2-2.2$ & $0.38-0.71$ \\
\hline 4 & P11 & 63 & 0.7 & $5.2 \pm 0.5$ & $4.1-5.1$ & $0.13-0.16$ \\
\hline 5 & $\mathrm{P} 12$ & 47 & 0.6 & $2.3 \pm 0.5$ & $1.4-2.4$ & $0.27-0.46$ \\
\hline 5 & $\mathrm{P} 13$ & 49 & 0.4 & $2.7 \pm 0.5$ & $1.7-2.7$ & $0.15-0.22$ \\
\hline 5 & $\mathrm{P} 14$ & 45 & 1.3 & $5.8 \pm 0.5$ & $4.9-5.9$ & $0.22-0.27$ \\
\hline 5 & P15 & 39 & 0.3 & $3.0 \pm 0.5$ & $2.2-3.2$ & $0.09-0.13$ \\
\hline 5 & P16 & 46 & 0.3 & $2.9 \pm 0.5$ & $2.0-3.0$ & $0.08-0.13$ \\
\hline 5 & P17 & 51 & 0.5 & $5.1 \pm 0.5$ & $4.1-5.1$ & $0.10-0.13$ \\
\hline 6 & P18 & 44 & 0.8 & $4.3 \pm 0.5$ & $3.4-4.4$ & $0.19-0.24$ \\
\hline 7 & P19 & 37 & 0.6 & $3.5 \pm 0.5$ & $2.6-3.6$ & $0.16-0.23$ \\
\hline 7 & $\mathrm{P} 20$ & 40 & 0.8 & $5.0 \pm 0.5$ & $4.1-5.1$ & $0.16-0.20$ \\
\hline 7 & $\mathrm{P} 21$ & 40 & 1.0 & $5.6 \pm 0.5$ & $4.7-5.7$ & $0.17-0.20$ \\
\hline 7 & $\mathrm{P} 22$ & 37 & 0.7 & $5.4 \pm 0.5$ & $4.5-5.5$ & $0.12-0.14$ \\
\hline 8 & $\mathrm{P} 23$ & 40 & 0.7 & $5.2 \pm 0.5$ & $4.3-5.3$ & $0.12-0.15$ \\
\hline 9 & $\mathrm{P} 24$ & 42 & 0.3 & $2.8 \pm 0.5$ & $1.9-2.9$ & $0.11-0.17$ \\
\hline 9 & $\mathrm{P} 25$ & 46 & 0.6 & $4.1 \pm 0.5$ & $3.2-4.2$ & $0.15-0.19$ \\
\hline 10 & $\mathrm{P} 26$ & 41 & 0.5 & $4.1 \pm 0.5$ & $3.2-4.2$ & $0.11-0.15$ \\
\hline 11 & $\mathrm{P} 27$ & 40 & 0.3 & $3.3 \pm 0.5$ & $2.4-3.4$ & $0.08-0.12$ \\
\hline
\end{tabular}

\footnotetext{
${ }^{\mathrm{a}}$ Calculated using EQ 1.
} 


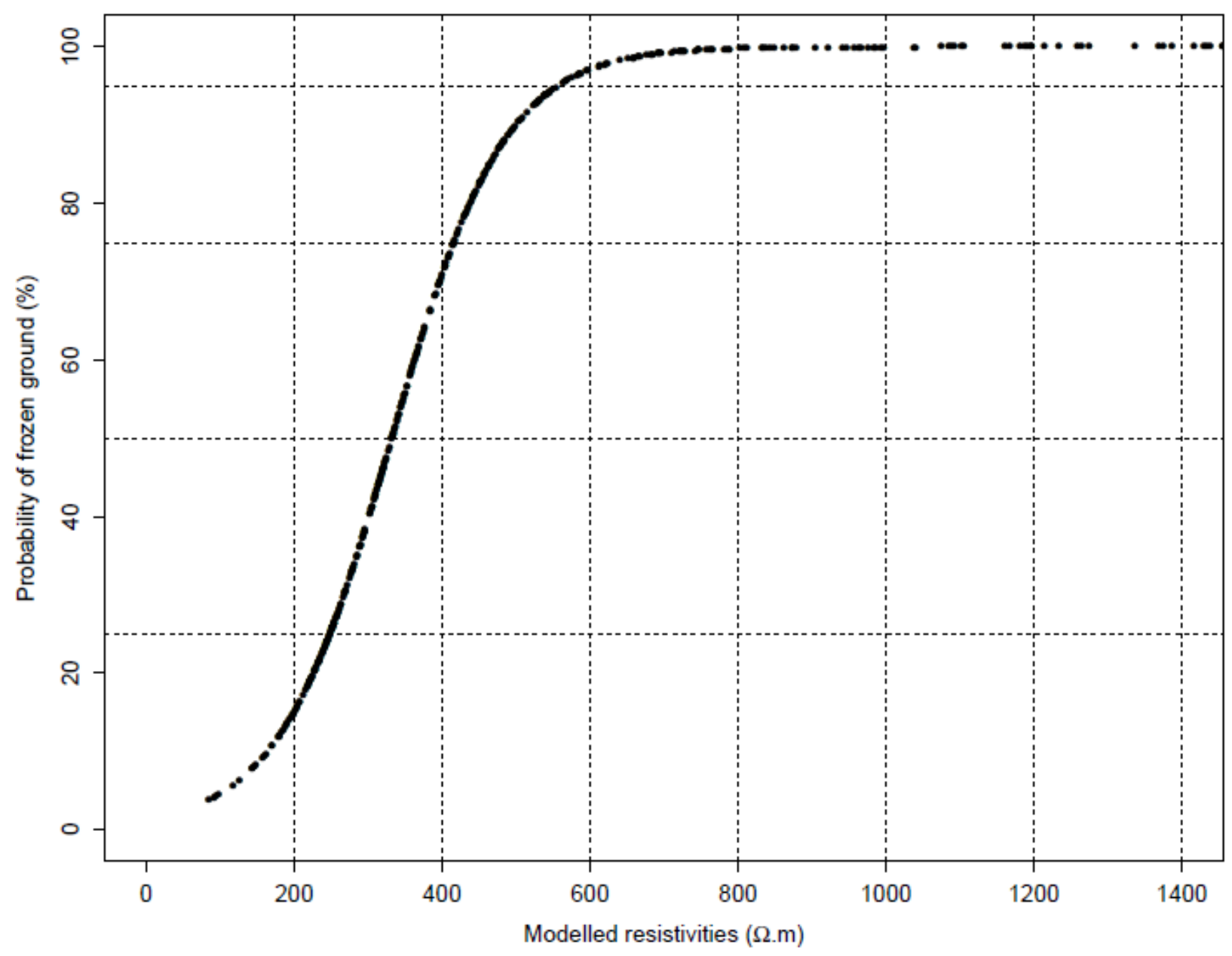

Figure S1: Logistic regression curve (AIC: 358.01; pseudo ${ }^{2}$ : 0.4) generated from co-located observations of frozen ground (thaw depth probing) and near-surface modelled resistivities extracted from model blocks (typically 0.5-1.0 m depths). 

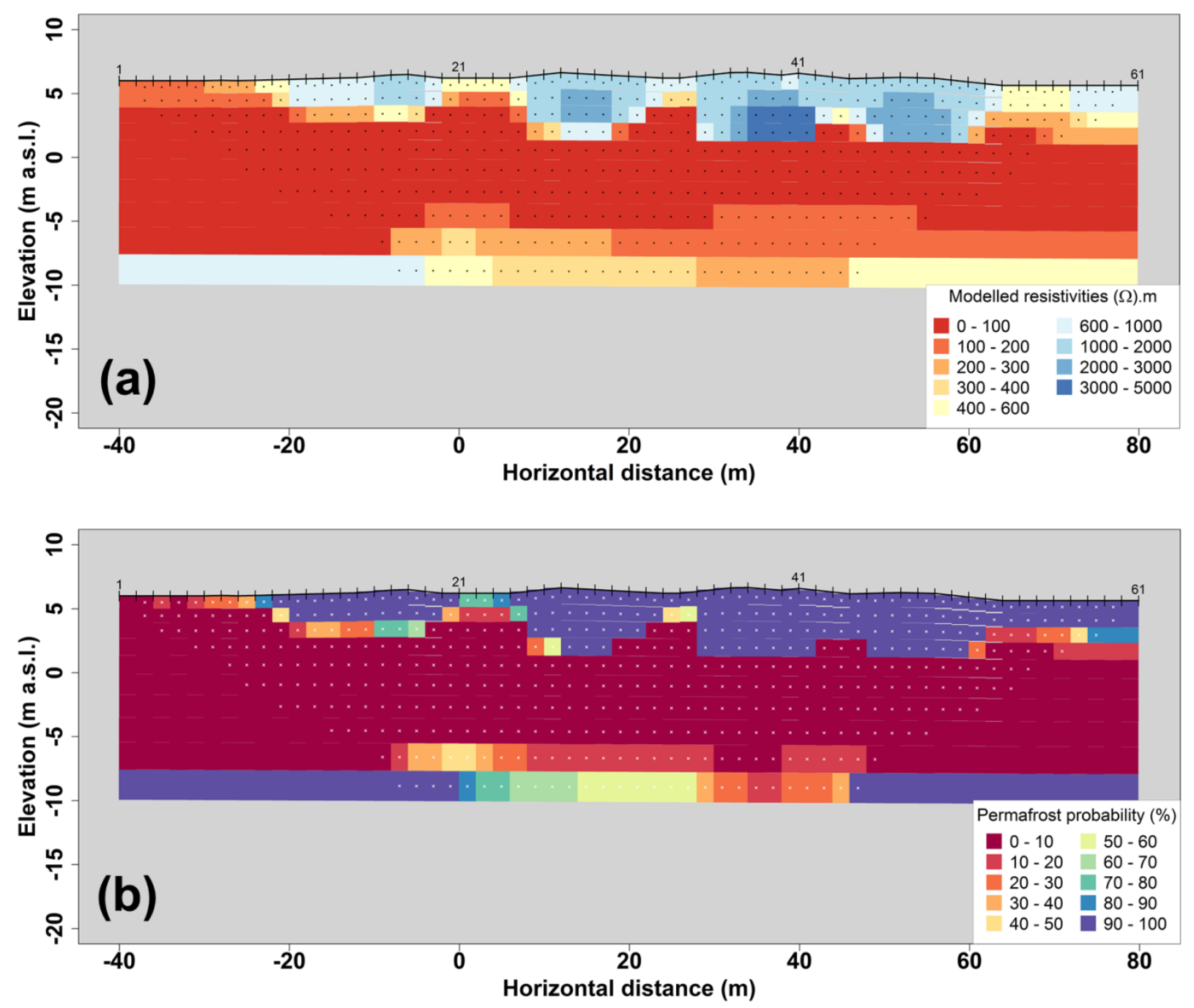

Figure S2: ERT profile \#7 from Cartwright, NL. (a) Profile depicting the modelled resistivities; (b) Profile of predicted permafrost probabilities derived using the logistic regression curve presented in S1 with the data presented in (a). Hatching shows standard plot depth of investigation presented in RES2DINV. Plots of profiles were generated in R v3.3 using a custom script. 

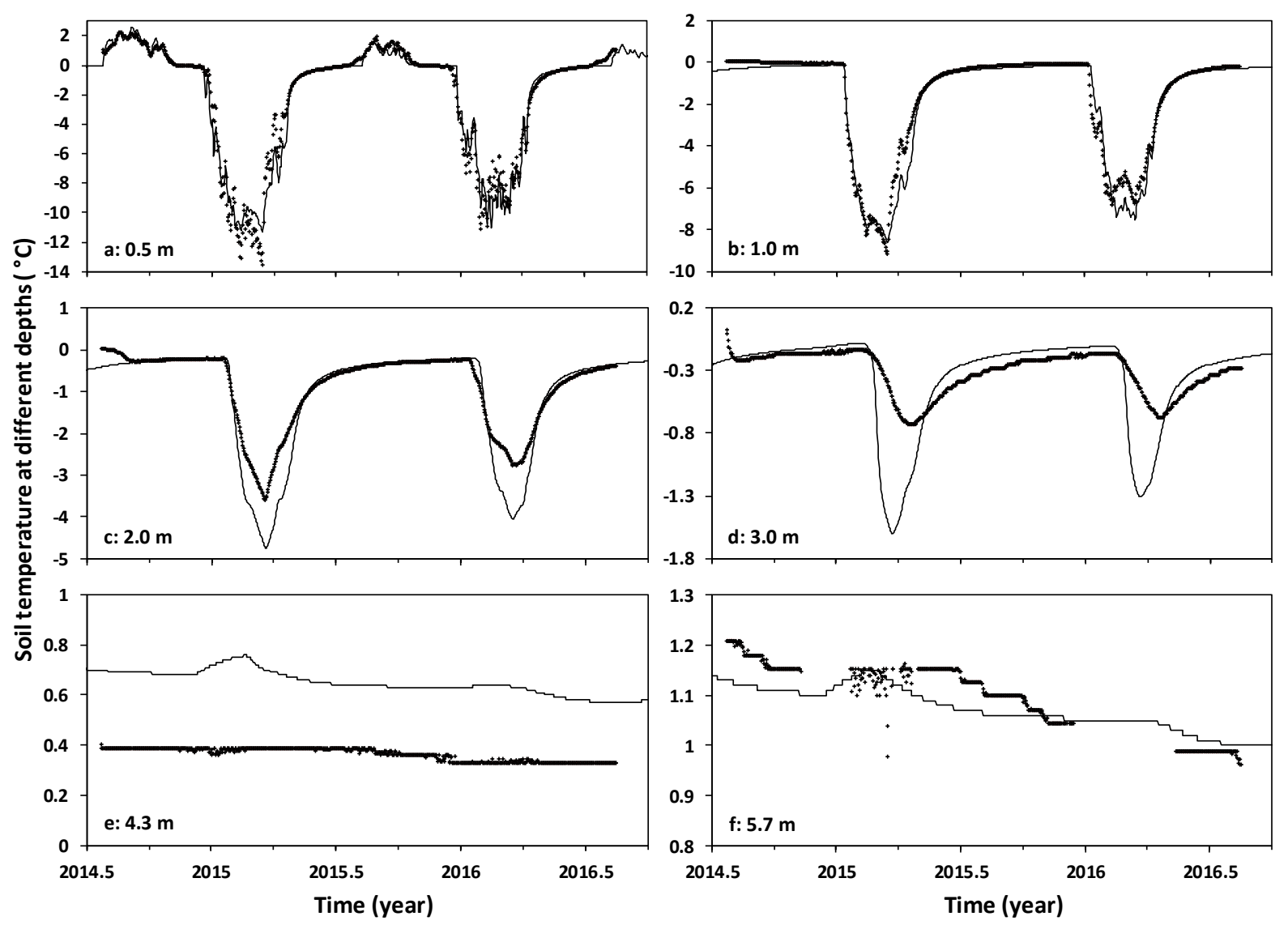

Figure S3. Comparison of modelled and measured temperatures at different depths at the Cartwright (WJD02) borehole, 2014-2016. The thin lines are modelled and the crosses are measured values. The depths are shown in the panels. At $0.5 \mathrm{~m}, \mathrm{n}=755 ; \mathrm{r}^{2}=0.94$; mean difference: $-0.1{ }^{\circ} \mathrm{C}$; mean absolute difference: $0.75^{\circ} \mathrm{C}$. Note: temperature scales differ among the panels. 

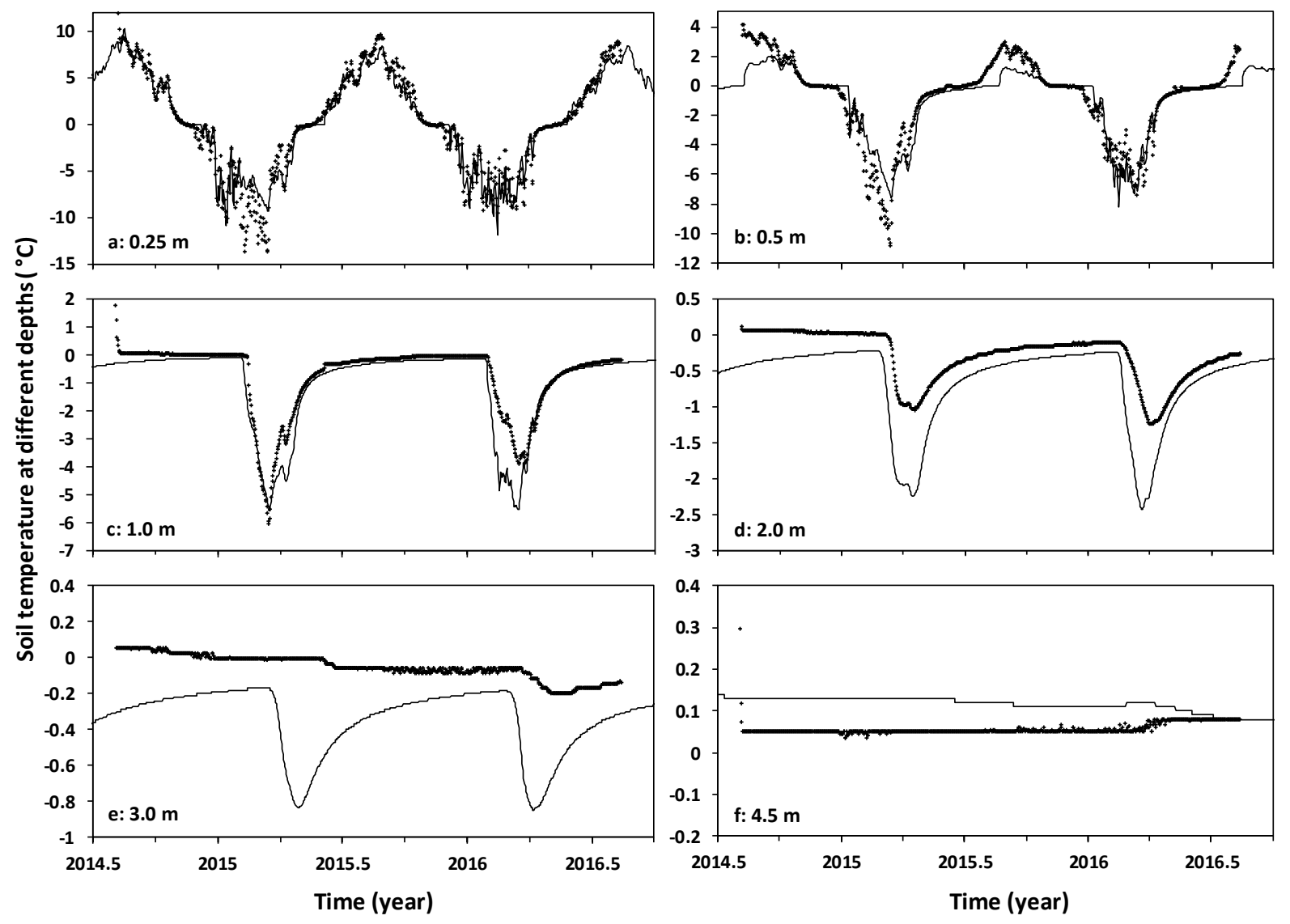

Figure S4. Comparison of modelled and measured temperatures at different depths at the Blanc Sablon (WJD03) borehole, 2014-2016. The thin lines are modelled and the crosses are measured values. The depths are shown in the panels. At $0.25 \mathrm{~m}, \mathrm{n}=621 ; \mathrm{r}^{2}=0.94$; mean difference: $-0.14^{\circ} \mathrm{C}$; mean absolute difference: $0.93^{\circ} \mathrm{C}$. Note: temperature scales differ among the panels. 


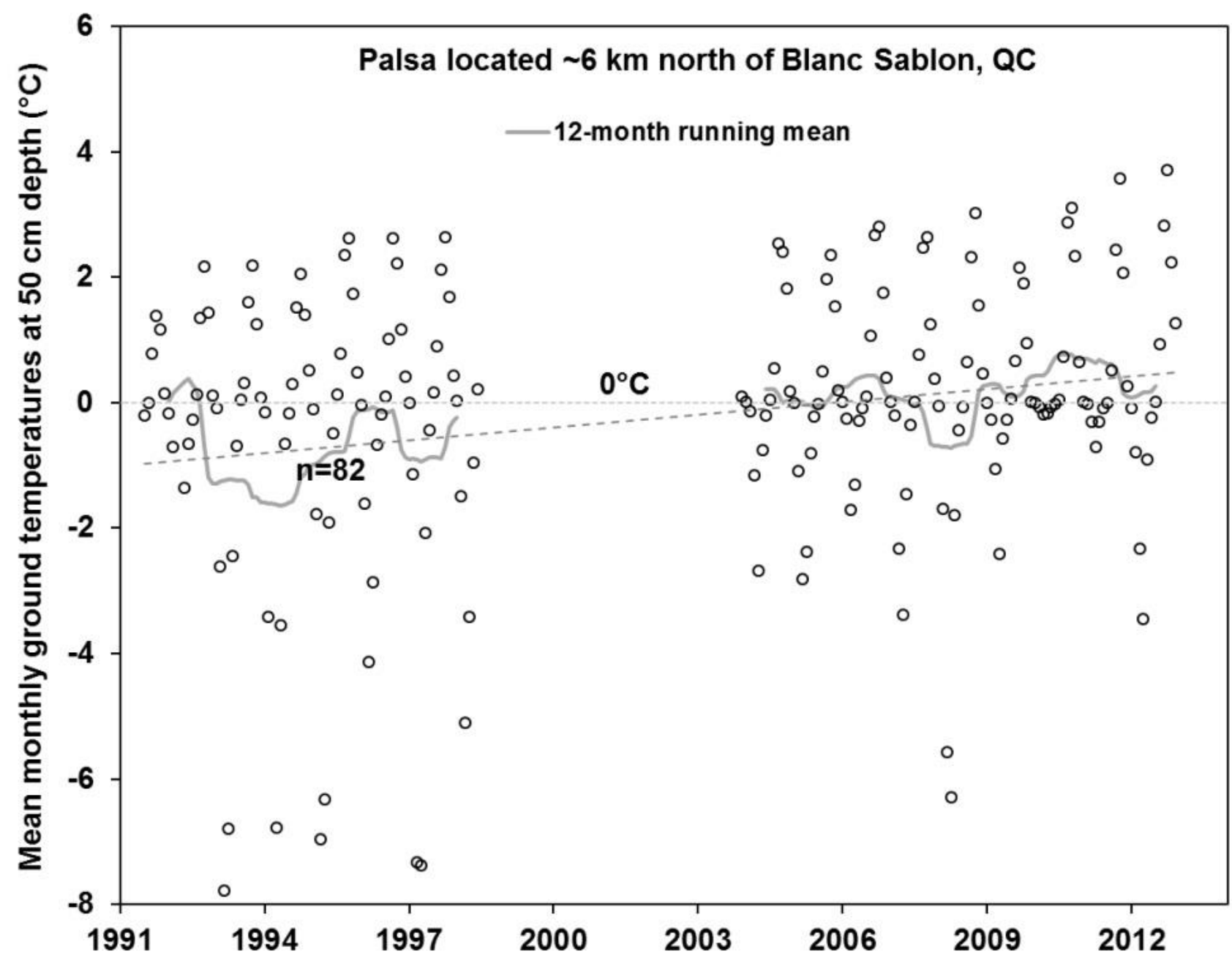

Figure S5. Monthly ground temperatures ( $\mathrm{n}=82$; black open circles) measured at $50 \mathrm{~cm}$ depth (1991-2012) on a palsa surface, about 6 km north of Blanc Sablon site (from Allard et al. 2014). 


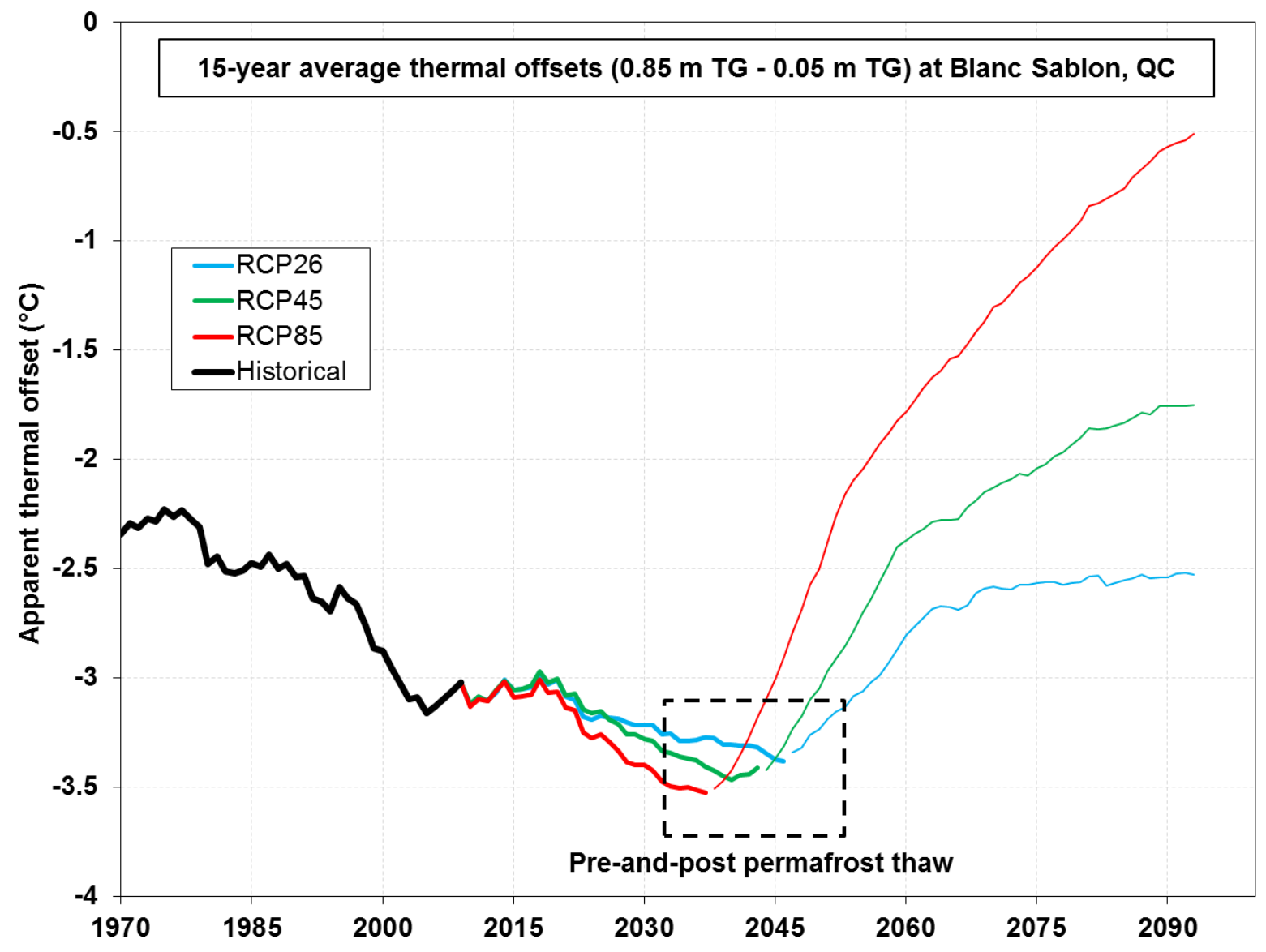

Figure S6. Centred 15-year average apparent thermal offsets for historical and future climate scenarios at Blanc Sablon, QC. Thicker lines denote the presence of permafrost and thinner lines denote the absence of permafrost. 


\section{References}

Brown, R., Lemay, M., Allard, M., Barrand, N. E., Barrette, C., Bégin, Y., Bell, T., Bernier, M., Bleau, S., Chaumont, D., Dibike, Y., Frigon, A., Leblanc, P., Paquin, D., Sharp, M. J. and Way, R.: Climate variability and change in the Canadian Eastern Subarctic IRIS region (Nunavik and Nunatsiavut), in Nunavik and Nunatsiavut: From science to policy. An Integrated Regional Impact Study (IRIS) of climate change and modernization, pp. 57-93. Available from: http://www.mun.ca/geog/Chapter_2.pdf, 2012.

Dell, C. I. A study of the mineralogical composition of sand in southern Ontario. Can. J. Soil. Sci., 39, 185-196, 1959.

Ekström, M., Grose, M. R. and Whetton, P. H.: An appraisal of downscaling methods used in climate change research, Wiley Interdisciplinary Reviews: Climate Change, 6(3), 301-319, doi:10.1002/wcc.339, 2015.

Environment Canada and National Research Council of Canada. Canadian Energy and Engineering Data Sets (CWEEDS) and Canadian Weather for Energy Calculations (CWEC) (CDROM), 2007.

Grenier, P., de Elía, R. and Chaumont, D.: Chances of Short-Term Cooling Estimated from a Selection of CMIP5-Based Climate Scenarios during 2006-35 over Canada, Journal of Climate, 28(8), 3232-3249, doi:10.1175/JCLI-D-14-00224.1, 2015.

Houldcroft, C.J., W.M. Grey, M. Barnsley, C.M. Taylor, S.O. Los, and P.R. North. New vegetation albedo parameters and global fields of soil background albedo derived from MODIS for use in a climate model. J. Hydrometeor., 10, 183-198, 2009. doi: 10.1175/2008JHM1021.1

McKenney, D. W., J. H. Pedlar, P. Papadopol, M. F. Hutchinson. The development of 1901-2000 historical monthly climate models for Canada and the United States. Agricultural and Forest Meteorology, 138, 69-81, 2006. doi: 10.1016/j.agrformet.2006.03.012

McKenney, D. W., M. F. Hutchinson, P. Papadopol, K. Lawrence, J. Pedlar, K. Campbell, E. M. Milewska, R. Hopkinson, D. Price, and T. Owen. Customized spatial climate models for North America. Bulletin of the American Meteorological Society, 92, 1611-1622, 2011. doi:10.1175/2011BAMS3132.1.

Pollack, H. N., S. J. Hurter, and J. R. Johnson. Heat flow from the Earth's interior: Analysis of the global data set. Rev. Geophys., 31, 267-280, 1993.

Taylor, K.E., R.J. Stouffer, and G.A. Meehl. An Overview of CMIP5 and the Experiment Design. Bulletin of the American Meteorological Society, 93, 485-498, 2012. doi: 10.1175/BAMS-D-1100094.1.

Way, R. G. and Viau, A. E.: Natural and forced air temperature variability in the Labrador region of Canada during the past century, Theoretical and Applied Climatology, 121(3-4), 413-424, doi:10.1007/s00704-014-1248-2, 2015.

Zhang, Y., Li, C., Trettin, C.C., Li, H., and Sun, G., An integrated model of soil, hydrology and vegetation for carbon dynamics in wetland ecosystems. Global Biogeochemical Cycles, 16(4), 1061, 2002. doi: 10.1029/2001GB001838. 
Zhang, Y., J. Li, X. Wang, W. Chen, W. Sladen, L. Dyke, L. Dredge, J. Poitevin, D. McLennan, H. Stewart, S. Kowalchuk, W. Wu, G. P. Kershaw, and R. K. Brook. Modelling and mapping permafrost at high spatial resolution in Wapusk National Park, Hudson Bay Lowlands. Can. J. Earth Sci., 49(8), 925-937, 2012. doi: 10.1139/e2012-031. 